\title{
Assessment of genetic variability among different genotypes of Cape gooseberry (Physalis peruviana L.) in India
}

\author{
Vikash Kumar ${ }^{*}$, Sanjay Sahay ${ }^{1}$, Vishal Nirgude ${ }^{1}$, Amrita Kumari², Ravi S. Singh ${ }^{3}$, \\ Hidayatullah Mir ${ }^{1}$, Shiv S. Mahesh ${ }^{1}$, Vinod Kumar ${ }^{2}$ \\ ${ }^{1}$ Department of Horticulture (Fruit \& Fruit Technology), Bihar Agricultural University, Sabour, Bhagalpur- 813210 \\ (Bihar), INDIA \\ ${ }^{2}$ Department of Horticulture (Vegetables and Floriculture), Bihar Agricultural University, Sabour- 813210 (Bihar), \\ INDIA \\ ${ }^{3}$ Department of Plant Breeding and Genetics, Bihar Agricultural College, Bihar Agricultural University, Sabour, \\ Bhagalpur- 813210 (Bihar), INDIA \\ *Corresponding author. E-mail: contact2vikash0089@gmail.com
}

Received: September 25, 2016; Revised received: March 20. 2017; Accepted: August 16, 2017

\begin{abstract}
The field experiment was carried out at the research farm of Horticulture Garden, Bihar Agricultural College, Sabour, Bhagalpur during 2014-15 for assessment of genetic variability among different genotypes of cape gooseberry in India. The experiment was laid out in Randomized Block Design with three replications having twelve genotypes. Analysis of variance revealed significant differences among genotypes for all the traits studies which suggesting sufficient variability for yield and quality parameters. The overall values of phenotypic coefficient of variation (PCV) were higher than those of genetic coefficient of variation (GCV). Higher magnitude of GCV and PCV were recorded for fruit per plant percent (33.30 and 36.61) followed by fruit diameter, fruit weight and flowers per branch. The maximum GCV (33.30) and PCV (36.61) were recorded in fruits/plant respectively. The high values of GCV are the indication of excess variability among the genotypes and thus the scope for crop improvement depends on the selection of superior parents for crossing to get better parents for hybridization. In present study, the magnitude of heritability ranged from $37 \%$ to $98 \%$ indicating that these traits are controlled by additive gene action which is very useful in selection. The traits like plant girth, plant height, inter nodal length, appearance of $50 \%$ of flowering, bud break to full bloom, number of flowers per branch, number of fruits set per branch, duration of fruit set to maturity, fruit weight, fruit diameter and number of fruits per plant with high GCV, PCV, heritability and genetic advance as percentage of mean, indicating that these characters are under additive gene effects and more reliable for effective selection.
\end{abstract}

Keywords: Cape gooseberry, GCV, Genetic advance, Heritability, PCA

\section{INTRODUCTION}

Cape gooseberry is botanically known as Physalis peruviana L. which belong to family Solanaceae. It is commonly called as "Poha" in Hawaii, Golden Berry in South Africa, and Rasbhari, Makoi or Tepari in India (Gupta and Roy, 1980). The first description of Physalis genus was made by Linnaeus in 1753 . The genus Physalis having approximately more than 120 species (Licodiedoff et al., 2013). such as, clammy ground cherry $(P$. heterophylla), tomatillo ( $P$. ixocarpa), purple ground cherry $(P$. philadelphica), strawberry tomato $(P$. pruinosa), husk tomato $(P$. pubescens) and sticky ground cherry ( $P$. viscosa) etc, which have distributed in warm and temperate climates of Africa, Asia and the America (Bala and Gupta, 2011). Menzel (1951) suggested that Cape gooseberry is tetraploid in nature and having chromosome number $2 \mathrm{n}=48$. Physalis is a climacteric fruit which shows a clear rise in ethylene production during ripening (Trinchero et al., 1999; Majumder and Mazumdar, 2002 and Gutierrez et al., 2008).

The fruit is small in size and round in shape which gives the bright orange in colour and sweet in taste. A number of species in the genus are of horticultural and economic importance due to their high nutritional value in vitamin $\mathrm{A}, \mathrm{C}$ and $\mathrm{B}$ complex, minerals and antioxidants as well as potential medicinal properties including anti-bacterial, anti-inflammatory, and anticancer properties (Strik, 2007).

The crop improvement programme mainly depends on the selection of superior parents for crossing to get better parents for hybridization and the knowledge of compatibility and magnitude of gene action which involved in the expression of important traits. Genetic variability is essentially the first step of plant breeding for crop improvement which is considered as the reservoir of variability for different characters (Vavilov, 
1951). High variations of morphological characteristics have been observed which used to identify the variability among different genotypes in Physalis. However, phenotypic characters are generally influenced by environments as well as plant developmental stages. In addition, species with similar morphological characters cannot be easily distinguished. Heritability and genetic advance help in determining the influence of environment in expression of characters and the extent to which improvement is possible after selection (Robinson et al., 1949). Heritable variation can be effectively studied in conjunction with genetic advance. High heritability alone is not enough to make efficient selection in segregating generation and needs to be accompanied by a substantial amount of genetic advance (Johanson et al., 1955). Identification of genotypes based on morphological characters implies culture inspection at different stages and is not very reliable because many traits of interest have low heritability and are genetically very complex. Hence, an insight into the magnitude of variability present in available accessions of physalis. It is importance to a plant breeder for starting a judicious breeding programme (Kaushik et al., 2011). By keeping the above facts in the mind, the present investigation was carried out for analyzing the amount of genetic variation in cape gooseberry accessions and categorizing to assist in selection of genotypes in a breeding programme.

\section{MATERIALS AND METHODS}

The present investigation was carried out at the research farm of Horticulture Garden, Bihar Agricultural College, Sabour, Bhagalpur $\left(87^{0} 2^{\prime} 42^{\prime \prime}\right.$ E, $\left.25^{\circ} 15^{\prime} 40^{\prime \prime} \mathrm{N}\right)$ at an altitude of $46 \mathrm{~m}$ above mean sea level in the heart of vast Indo-Gangatic plains of north India. The climate of this place is sub-tropical in nature which characterized by dry summer, moderate rainfall and cold winter. January and February are usually the coldest months whereas the mean temperature normally falls as low as $10.4^{\circ} \mathrm{C}$ and April \& May are generally the hottest months having the maximum average temperature of $37^{\circ} \mathrm{C}$. The experiment was laid out in Randomized Block Design with three replication. The experimental material consists of twelve genotypes of Cape gooseberry (Physalis peruviana L.) viz., CITH Sel-1, CITH Sel-3, CITH Sel-5, CITH Sel-7, CITH Sel-9, CITH Sel-11, CITH Sel-15, CITH Sel-16, SS/VK/301, SS/VK/401, SS/VK/501 and $S S / V K / 601$. Seeds are sown in the protray that consist Cocopeat: vermicompost: sand with ratio 2:1:1/2 in the month of August of 2014. The field was irrigated immediately after planting. All the recommended agronomic package of practices was followed. These seedlings were ready for transplanting after 3-4 weeks and transplanting was done after one month. Each genotype is planted at a spacing of $60 \mathrm{~cm}$ between row-to-row and $60 \mathrm{~cm}$ between plant-plant. Planting of rooted seedling was done in the evening. The observation were recorded on five randomly selected plants per replication for each germplasm on eleven quantitative characters, viz., plant girth, plant height, inter nodal length, appearance of $50 \%$ of flowering, bud break to full bloom, number of flowers per branch, number of fruits set per branch, duration of fruit set to maturity, fruit weight, fruit diameter and number of fruits per plant of twelve cape gooseberry genotypes collected from CITH Srinagar (8 genotypes) and other local (4 genotypes) collected from Bihar region. Recorded values were subjected to statistical analysis of variance and co-variance as prescribed by Burton and Devane (1953). Heritability $\left(\mathrm{h}^{2}\right)$ in broad sense (Lush, 1949) being the ratio of genotypic variance to phenotypic variance was calculated. Broad sense heritability $\left(h^{2}\right)$ estimates were classified as low, moderate and high as below given by Robinson et al. (1966). The expected genetic advance was worked out as suggested by Johnson et al. (1955).

\section{RESULTS AND DISCUSSION}

Variability parameters: The extent of variability with respect to eleven quantitative characters in twelve genotypes measured in term of mean performance,

Table 1. Analysis of variance for eleven characters in cape gooseberry.

\begin{tabular}{|c|c|c|c|c|}
\hline \multirow[b]{2}{*}{ S. N. } & \multirow[b]{2}{*}{ Characters } & \multicolumn{3}{|c|}{ Mean sum of squares } \\
\hline & & $\begin{array}{l}\text { Replication } \\
\text { d.f.:2 }\end{array}$ & $\begin{array}{l}\text { Treatments } \\
12\end{array}$ & Error's \\
\hline 1. & Height of plant $(\mathrm{cm})$ & 244.08 & $433.33 * *$ & 104.25 \\
\hline 2. & Plant girth $(\mathrm{cm})$ & 0.03 & $0.11 *$ & 0.04 \\
\hline 3. & Inter nodal length $(\mathrm{cm})$ & 0.32 & $23.01 * *$ & 1.09 \\
\hline 4. & Period of $50 \%$ of flowering (days) & 0.27 & $562.02 * *$ & 23.47 \\
\hline 5. & Period of bud break to full bloom(days) & 0.19 & $0.79 * *$ & 0.19 \\
\hline 6. & Number of flower per branch & 0.01 & $26.03 * *$ & 0.44 \\
\hline 7. & Number of fruit set per branch & 0.70 & $15.11 * *$ & 0.96 \\
\hline 8. & Duration of fruit set to maturity(days) & 16.08 & $78.96 * *$ & 8.81 \\
\hline 9. & Fruit weight(g) & 0.09 & $50.40 * *$ & 3.29 \\
\hline 10. & Fruit diameter (mm) & 1.90 & $192.97 * *$ & 2.04 \\
\hline 11. & Number of fruits per plant & 26.00 & $1948.26 * *$ & 126.82 \\
\hline
\end{tabular}

*, ** Significant at $0.05 \%$ and $0.01 \%$ probability level, respectively 
Vikash Kumar et al. / J. Appl. \& Nat. Sci. 9 (3): 1735 -1739 (2017)

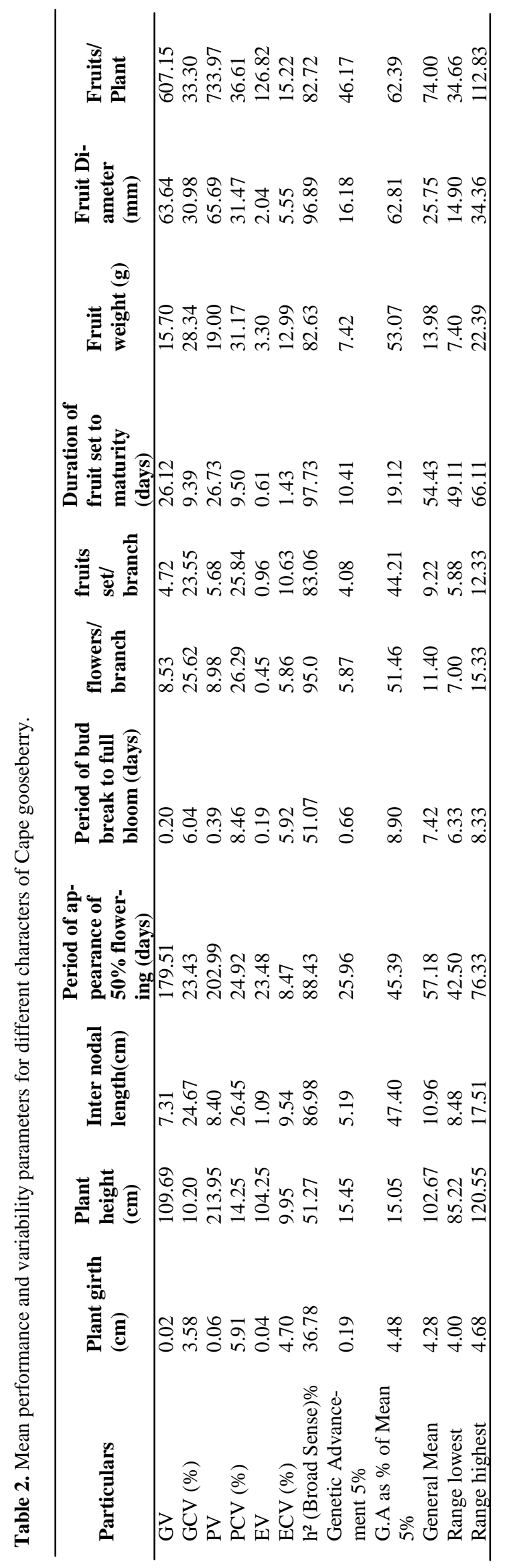

phenotypic coefficient of variation (PCV), genotypic coefficient of variation (GCV), heritability, genetic advance and genetic advance as percent of mean are given in Table 2. The advancement of variability which denotes a genotype tends to vary between among genotypes and response to environmental and genetic factors. The analysis of variance for design of experiment was done for portioning the variance into treatments and replications according to procedure given by Panse and Sukhatme (1967). The analysis of variance indicated significantly higher amount of variability among the genotypes for all the characters studied Table 1.

Estimates of different genetic variability parameters are presented in Table 2. Results showed that The range of variation was high for fruit per plant (34.66-112.83), also reported in tomato by Ghosh et al. (2010) and Kaushik et al. (2011), Basavaraj et al. (2015) and Kumar et al. (2016) and followed by period of $50 \%$ of flowering $(42.50-76.33 \mathrm{~cm})$ and plant height $(85.22-120.55 \mathrm{~cm})$ and the lowest genotypic variance was that of plant girth (4.00$4.68 \mathrm{~cm})$. In present investigation, highest genotypic and phenotypic variance were recorded for fruit per plant (607.15 and 733.97) followed by period of $50 \%$ flowering (179.51) in genotypic variance and plant height $(213.95 \mathrm{~cm})$ in phenotypic variance respectively, whereas, the lowest for plant girth $(0.02 \mathrm{~cm}$ and $0.06 \mathrm{~cm})$. High genotypic coefficient of variation (GCV) indicating more contribution of genetic component for the total variation. Therefore, these characters could be considered and exploited for selection purpose whereas high phenotypic variance indicating the strong influence of environmental factors for their expression. The phenotypic coefficient of variation (PCV) were higher than genotypic coefficient of variation $(\mathrm{GCV})$ for all the traits studies which is an indicator of additive effect of the environment on the expression of the trait. Higher magnitude of GCV and PCV, respectively were recorded for fruit per plant (33.30 and 36.61) followed by fruit diameter $(30.98 \mathrm{~mm}$ and $31.47 \mathrm{~mm})$ whereas lowest for plant girth $(3.58 \mathrm{~cm}$ and $5.91 \mathrm{~cm})$ which indicating higher magnitude of variability for these characters. Moderate range was found for plant height $(10.20 \mathrm{~cm}$ and $14.25 \mathrm{~cm})$ which were manifested by Singh and Kumar (2005) and they concluded that moderate phenotypic and genotypic coefficient of variation (10 to 19\%) were observed for plant height in brinjal. however, narrow range of genotypic coefficient of variance were recorded in characters like, plant girth $(3.58 \mathrm{~cm}$ and $5.91 \mathrm{~cm})$, bud break to full bloom $(6.04$ and 8.46) and fruit set to maturity (9.39 and 9.50). Pradeep et al., 2001 reported in tomato that high genotypic coefficient of variance and phenotypic coefficient of variance was for number of fruits/ 
plant (58.07 and 68.21). The moderate amount of GCV and PCV, respectively were recorded for plant height $(10.20 \mathrm{~cm}$ and $14.25 \mathrm{~cm})$. High values of GCV are an indication of high genetic variability among the genotypes and thus the scope for improvement of these characters through simple selection would be better. The differences between GCV and PCV was minimum for fruit set to maturity (9.39 and 9.50) and other traits having scanty variation found which are suggesting that these traits were least affected by environment.

Heritability and genetic advance: Heritability $\left(h^{2}\right)$ is the in broad sense (Lush, 1949) being the ratio of genotypic variance to phenotypic variance was calculated as per formula suggested by Burton and Devane (1953). In present study, all the characters showed high heritability, the magnitude of heritability ranged from $37 \%$ to $98 \%$ indicating that these traits are controlled by additive gene action. The highest heritability was recorded on duration of fruit set to maturity $(97.73 \%)$ followed by fruit diameter $(96.89 \%)$, number of flower per branch $(95.03 \%)$, period of appearance of $50 \%$ of flowering $(88.43 \%)$, inter nodal length $(86.98 \%)$, fruit set per branch $(83.06 \%)$, fruits per plant $(82.72 \%)$, plant height $(51.27 \%)$, period of bud break to full bloom (51.07\%) and plant girth (36.78\%). High heritability in tomato was exhibited for number of fruits per plant (84 to $99.5 \%$ ) which was reported by Basavaraj et al. (2015), Nagariya et al. (2015) and Kumar et al. (2016). The high values of heritability estimates in broad sense indicated that sustainable improvement can be made using standard selection procedures. The estimate of genetic advance showed a wide range from $0.19 \mathrm{~cm}$ for plant girth to 46.17 for fruit per plant.

\section{Conclusion}

The genetic architecture of fruits per plant is based on the balance or overall net effect which produced by various characteristics components interacting with one another characteristics of Physalis genotypes. Based on the studies on genetic variability, it may be concluded that, the characters such as fruits per plant (33.30), fruit diameter (30.98), fruit weight (28.34), flowers per branch (25.62), inter nodal length (24.67), fruit set per branch (23.55) and period of $50 \%$ of flowering (23.43) recorded high amount of genetic variability along with heritability and genetic advance. However, the difference between GCV and PCV was low in most of the character studied. It reveals that there is a greater scope for improving these characters by simple phenotypic selection. For breeding point of view, heterosis is the best way to improve this trait for future.

\section{ACKNOWLEDGEMENTS}

The authors are thankful to Chairman, Department of
Horticulture, Bihar Agricultural College, Bihar Agricultural University, Sabour, India for providing all the required infrastructure and facilities for the present work.

\section{REFERENCES}

Bala, S. and Gupta, R.C. (2011). Effect of secondary associations on meiosis, pollen fertility and pollen size in cape gooseberry (Physalis peruviana L.). Chrom. Bot., 6: 2528.

Basavaraj, L.B., Vilas, D.G. and Vijaykumar, R. (2015). Study on genetic variability and characters interrelationship of quality and yield components in tomato (Solanum lycopersicum L.). HortFlora Research Spectrum, 4(2):108-115.

Burton, G.W. and Devance, E.H. (1953). Estimating heritability in tall Fescue from replicated clonal material. Agron. J., 45: 474-481.

Ghosh, K. P., Islam, A. K. M. A., Mian, M. A. K. and Hossain, M. M. (2010). Variability and character association in F2 segregating population of different commercial hybrids of tomato (Solanum lycopersicum L.). J. Appl. Sci. Environ. Manage., 14: 91-95.

Gupta, S.K. and Roy, S.K. (1980). Multipurpose cape gooseberry. Indian J. Hort., 24(4): 11.

Gutierrez, M.S., Trinchero, G.D., Cerri, A.M., Vilella, F. and Sozzi, G.O. (2008). Different responses of golden berry fruit treated at four maturity stages with the ethylene antagonist 1-methylcyclopropene. Postharvest Biol. Technol., 48: 199-205.

Johnson, W.W., Robinson, H.F. and Comstock, R.E. (1955). Genotypic and phenotypic correlation in Soybeans and their implications in selection. Agron. J., 47: 477-482.

Kaushik, S. K., Tomar, D. S. and Dixit, A. K. (2011). Genetics of fruit yield and it's contributing characters in tomato (Solanum lycopersicum). J. Agric. Biotech. Sustainable Devlop., 3(10): 209-213.

Kumar, K., Sharma, D., Trivedi, J. and Kumar, D. (2016). Genetic variability, heritability and genetic advance for fruit yield and yield attributes in cherry tomato (Solanum lycopersicum L. var. cerasforme). Environment \& Ecology, 34(2A):718-721.

Licodiedoff, S., Koslowski, L. A. D. and Ribani, R. H. (2013). Flavonols and antioxidant activity of Physalis peruviana L. fruit at two maturity stages. Acta Scientiarum. Technology, 35, 393-399.

Lush, J.L. (1949). Heritability of quantitative characters in Farm animals. Hereditas, 35: 356-375.

Majumder, K. and Mazumdar, B.C. (2002). Changes of pectic substances in developing fruits of cape-gooseberry (Physalis peruviana L.) in relation to the enzyme activity and evolution of ethylene. Sci. Hort., 96: 91-101.

Menzel, M.Y. (1951). The cytotaxonomy and genetics of Physalis. Proc. Americ. Philosop. Soci., 95: 132-83.

Nagariya, N.K., Mukherjee, S. and Sharma, N. (2015). Genetic variability, heritability and genetic advance in tomato (Solanum lycopersicon L.). Annals of Biology, 31(1):91-93.

Panse, V.G. and Sukhatme, P.V. (1967). Statistical method for agricultural research workers ICAR, New Delhi.

Pradeep, K.T., Bastian, D., Joy, M., Radhakrishan, N.V. and Aipe, K.C. (2001). Genetic variability in tomato for yield and resistance to bacterial wilt. J. Trop. Agric., 39: 
$157-158$.

Robinson, H.F., Comstock, R.E. and Harvey, P.H. (1949). Estimates of heritability and degree of dominance in corn. Agron. J., 41: 253-259.

Robinson, H.F., Comstock, R.E. and Harvey, P. (1966). Quantitative genetics in relation to breeding on the centennial of Mendelism. Indian J. Genet., 26: 171-177.

Singh, O. and Kumar, J. (2005). Variability, heritability and genetic advance in brinjal. Indian J. Hort., 62 (3): 265267.

Strik, B.C. (2007). Berry crops: Worldwide area and produc- tion systems. In: Zhao Y, editor. Berry Fruit: ValueAdded Products for Health Promotion. 1st ed. Boca Raton, FL, USA: CRC Press, Pp.3-50.

Trinchero, G., Sozzi, G., Cerri, A.M., Vilella, F. and Fraschina, A. (1999). Ripening-related changes in ethylene production, respiration rate and cell-wall enzyme activity in goldenberry (Physalis peruviana L.), a solanaceous species. Postharvest Biol. Technol., 16: 139-145.

Vavilov, N.I. (1951). The origin variation immunity and breeding of cultivated plant. Soil Sci., 72: 482. 

ERROR: syntaxerror

OFFENDING COMMAND: --nostringval--

\section{STACK :}

/ Title

()

/ Subject

(D:20170821180816+05'30')

/ModDate

( )

/Keywords

(PDFCreator Version 0.9.5)

/Creator

(D:20170821180816+05'30')

/CreationDate

(dell)

/Author

-mark- 